\title{
A Conspectus and Bibliography of Byelorussian Literature in the Nineteenth Century
}

\author{
BY
}

\author{
ARNOLD B. McMILLIN
}

The nineteenth century is one of the least known periods in the history of the Byelorussian literary language, a fact due at least in part to the inadequacy of existing information about the works of which it is comprised. The conspectus aims to place the main writers and texts in a general historical context, at the same time giving factual information relating to dates, place of origin or publication, authorship and the use of pseudonyms, whilst the bibliography is intended to provide a full list of those texts that have survived to the present day, with, where possible, their date of composition and date and place of first publication.

The present work assumes a broad definition of 'literary language' as the language of writing in general, rather than exclusively that of literature or belles-lettres. ${ }^{1}$ Purely folk (narodny) poetry is not included, and in distinguishing it from cultivated (štučny) verse the compiler has generally followed the guidance of Karski; however, the poems in Romanov's Belorusskij sbornik (I, 3, pp. 433-7) under the general title of Meloci $i$ appear too illiterate to warrant inclusion in a work of this kind. ${ }^{2}$ The other conscious omissions are of four poems published anonymously in Opyty $v$ russkoj slovesnosti vospitannikov gimnazij belorusskogo učebnogo olıruga, Vilna, 1839 (Byv na Rusi Čorny boh; Iz-za Słucka, iz-za Klecka; Oj, kołyb, koły moskali prišły and V lesie temnom $u$ Vyślicy) which, although occasionally mentioned as nineteenth-century works, ${ }^{3}$ were probably composed towards the end of the eighteenth century; also omitted are two fragments from the album of A. Viaryha-Dareŭski (a short verse by Mamiert Ren'je and a prose note by Rypinski) neither of which appear to the present writer to be written in Byelorussian. ${ }^{4}$

Any description of the writers and anonymous texts comprising nineteenth-century Byelorussian literature is bound to be incomplete.

1. See Robent Auty, 'Some Thoughts on the History of Literary Languages'. Cercetări de Lingvistică, III, Cluj, 1958, pp. 46-9.

2. Je. F. Karskij, Belorusy (subsequently referred to as Bel), III, 3, Petrograd, 1922 , p. 112.

3. I. I. Kramko, A. K. Jurevič, A. I. Janovič, Historyja bielaruskaj litaraturnaj movy, II, Minsk, 1968 (subsequently referred to as $H B L M$, II), pp. 19-20.

4. See, however, Adam Maldzis, Padarožža $\breve{u}$ XIX stahodździa, Minsk, 1969 (subsequently referred to as PXIX), p. 88. 
Many works, including the entire Byelorussian opus of some writers, although known to us from contemporary sources, are now lost. Discoveries and re-discoveries continue to be made, however, notably by scholars like I. Kramko, H. Kisialoŭ, A. Maldzis and S. Aleksandrovič, and one may hope that with time many additions to the bibliography will be made possible. Nonethsless, the present compilation is strictly confined to works which are known to have survived, and it omits all those like, for example, Viaryha-Dareŭski's poem Dumka chłopka $z$ okolic Witebsḱa na odgtos wolności (1858) which, although mentioned in relatively recent works, appears to have been lost. ${ }^{5}$

Although the bibliography only gives texts written in Byelorussian, a number of the works it lists are macaronic (for example, in DuninMarcinkievič's Sielanka only a few of the characters speak Byelorussian rather than Polish): such works include, in addition to the same author's Zaloty, ${ }^{6}$ Cačot's Jeżowe, Jaroszowe and Adamowe $i$ Tomaszowe, and the Krótkie zebranie nauki chrześcianskiey and Elementarz dla dobrych dzietok katolikou. Many more works have Polish or Russian titles but Byelorussian texts (Čačot's Własne piosnki or the Reč́ starovojta k krest'janam o svobode, for example), whilst others are simply mixed.

No rules for Byelorussian orthography were established before the end of the first decade of the twentieth century. In the nineteenth century, writers used both Latin and Cyrillic characters, some simply following the Polish and Russian literary norms of the time, others attempting, with varying success, to represent in their writing the main phonetic features of the Byelorussian language. In the present work the names of writers are given in their modern Byelorussian form, whilst the titles of works are presented, as far as possible, according to their first printed editions or manuscripts (transliterated where necessary).

Finally, where several nineteenth-century editions of the same work exist (Taras na Parnasie, for example), they are all given, in chronological order.

\section{CONSPECTUS}

Although in the fifteenth and sixteenth centuries the Byelorussian language had flourished in both an official and also a literary capacity, the growth of dynastic ties between the Grand Duchy of Lithuania and Poland, culminating in the Union of 1569, inevitably led to the linguistic and cultural polonisation of the Byelorussian

5. See Bel, III, 3, p. 66; HBLM, II, p. 50.

6. In the first printed edition of this play (Minsk. 1918), and in all subsequent editions, the Polish parts are given in the Byelorussian translation of Jankia Kupała. 
gentry, and the relegation of the language and the literary tradition to the level of purely popular usage and oral folk poetry. During the eighteenth century, it is true, the Byelorussian language in its spoken, unliterary form did play a part in the so-called 'school dramas' which arose in the Jesuit colleges and seminaries of that time; in these plays Byelorussian was spolen by the simpler characters as a form of buffoonery in contrast to the more 'noble' Polish speech of the heroes and heroines. Stich works however, were hardly designed to promote the Byelorussian language as a literary medium, and had little or no effect on the course of its development.

Thus, nineteenth-century Byelorussian writers were entirely cut off from the literary heritage of the Grand Duchy, even if they were aware of its existence. A few, like Bahuševič, had access to some of the old legal documents, ${ }^{7}$ but the translations, memoirs and other works that comprise Middle Byelorussian literature were virtually unknown; as a result, writers were compelled to turn to the popular language in order to create a new literary medium within which to work. Faced with increasingly determined opposition from the Russian authorities, their first steps were inevitably hesitant, and the overal picture presented by the nineteenth century is one of fragmentation; nonetheless, by the end of the period a number of genres had been successfully essayed, and a body of work created on which later writers, less harassed by external pressures, could build a modern literary language and literature worthy of the name.

The first really influential work of the nineteenth century was the anonymous Enieida navyvarat which originated in the north-east of Byelorussia and was first published in 1845, although internal evidence suggests that it was written in the early 1820 s. $^{8}$ Quite heavily russified and with a large number of dialectisms and invented forms, this comic travesty of the Aeneid is loosely based on I. Kotljarevskyj's Ukrainian imitation ${ }^{9}$ of $\mathrm{N}$. Osipov's Virgilijevaja Jenejda, vyvoročennaja na iznanku (St Petersburg, 1791). ${ }^{10}$ For a long time

7. See his introduction to Dudka bietoruskaja.

8. Many other anonymous works of this early period were not published unti] long after the time of composition; some were published by the Russian and Polish ethnographers of the second half of the century (Ab $\dot{z} \dot{y} c i$ i śmierci pjànicy, Chimka $z$ Hankoju, dźvie molodzicy, Hej, kab nam być viesielej, Hutarka Paŭluka, Kuźma siadzievši s Apanasom, Maladzikòwa Hùtarka, Novejšije stichi, Oj, viaśnica, viasna, Panskaja laska, Pozdravitel'noje stichotvorenije so dnjom angela, Prečistaja siered noči, Razhovor Danity i Sciepana (pro volu), Staryj Vosip borodatyj, Taras na Parnasie, U panov nikto biez sprosu, Viasna hola pierapala, Vinšovanije Savaścieja, Vot ciepier jaki lud stav, Vot vidicie vy, dzieci, jakije ciapier ludzi na śviecie). Even worl:s of known authorship (Abuchovič's Papiery, Arcimoŭski's Pani Tvardoǔskaja, Karatynski's Tuha na čžoj staranie or Syrakomla's Dobryja vieści, for example, were often published long after they were written.

9. The first copies of Kotljarevskyj's version date from 1794. See Bel, III, 3 , p. 10.

10. Translations from and imitations of Ukrainian works were not uncommon in the nineteenth century: for example, Hurynovič's Viečny revolucyjanier, Pro bahactvo da b'ednosć. P'eraklad s ukrajinskaho, or Vot ciepier jaki luci stav etc. See also Dziadźka Anton. 
its author was thought to be Tamaš Mańkoŭski, Vice-governor of Viciebsk and a former councillor in Mahiloŭ, but most modern scholars now attribute the work to Vincent Ravinski (b. 1786; d. 1855), a lieutenant from the Smolensk region. ${ }^{11}$ Extremely popular amongst the minor gentry, Enieida is significant in that, for all its crudeness, it drew attention to the literary possibilities of the Byelorussian language. A similar role was played by Taras na Parnasie, another comic narrative poem, also from north-east Byelorussia. Again the language is very down-to-earth and close to peasant speech, but Taras, probably written about ten years after Enieida is linguistically more organised than its predecessor. Some scholars, including Dounnar-Zapolski, ${ }^{12}$ associate Taras with the name of Dunin-Marcinkievič, although there seems to be little basis for this. Romanov believes it to have been written by students at the Horki (Mahiloŭ region) agricultural college which in 1864 moved to St Petersburg. ${ }^{13}$ It was not published until 1889, but like Enieida was well-known amongst the gentry and other literate members of the population in the first half of the century.

Although only one of his works survives, Paŭluk Bachrym (b. Krošyn, Haradzišča region $1818 ;^{14}$ d. Krošyn $1891^{15}$ ) is accorded a special place in the history of Byelorussian literature, being the first writer of purely peasant origin. By trade a blacksmith and ironworker, he was taught to read and write by the Catholic priest and populist Fr Mahnušeŭski. ${ }^{16}$ After the 1830 uprising many of his 'liberal' poems were confiscated by the police, and he was sentenced to twenty-five years in the ranks of the Imperial army. Zahraj, zahraj, chłopcze mały, his one surviving work, ${ }^{17}$ was written in about 1828 and reflects faithfully the writer's native dialect.

Jan Barščeŭski (b. Marohi, Viciebsk region 1794:18 d. Cudova, Volhynia 1351) and Radvan Rypinski (b. Dzisna region; d. 1840) were both from the liberal šlachta, and in addition to a considerable body of ethnographical work (in Polish) left a number of short verses in Byelorussian which reflect the dialects of their native regions. Both

11. Bel, III, 3, pp. 13-6. See also Je F. Karskij, 'Belorusskaja Eneida na iznanku. S priloženijem teksta sochranivšichsja otryvkov', Sbornik Char'kovskogo Istoriko-filologičeskogo Obščestva, XVIII, Char'kov, 1908-9, pp. 143-73; H. Kisialoŭ, 'Zahadka biełaruskaj Enieidy', Potymia, 1, pp. 208-29 and 2, pp. 191-206, Minsk, 1968.

12. M. Dovnar-Zapol'skij, 'Dunin-Marcinkevič i jego poema Taras na Parnase', Vitebslcije gubernskije vedomosti, 2-3, 6-7, 26-7, Viciebsk, 1896.

13. Je. R. Romanov, 'Taras na Parnase' $i$ drugije belorussicije stichotvorenija. Mahiloŭ, 1900 , p. 3.

14. Harecki gives 1814. M. Harecki, Chrystamatyja bietaruskaje litaratury XI vek - 1905 hod, Vilna, 1922 (subsequenitly referred to as HCh), p. 86.

15. Barysienka gives 1898 . V. V. Barysienka (ed.), Narysy pa historyi biclaruskaj litaratury, Minsk, 1956 (subsequently referred to as $N H B L$ ), p. 68 .

16. See A. Janułajtis, 'Ab maładym paecie z Krošyna', Maładaja Biełaruś, 3, St Petersburg, 1913, pp. 9-16.

17. R. Ziemkievič also attributes the anonymous Razhovor Danily $i$ Sciepana (pro volu) to Bachrym, but his reasons are not convincing. See M. Harecki, Historyja biełaruskaje litaratury, 4th edition, Minsk, 1926 (subsequently' referred to as $H H)$, p. 134.

18. Some authorities suggest 1790 . See PXIX, p. 25. 
travelled widely (Rypinski spent nearly ten years in exile) and drew the attention of Poles and Russians to the existence of Byelorussia as a rich and unexpiored source of ethnographical material. A similar role was played by the ethnographer and poet Jan Cačot (b. Malušycy, Kareličy region 1796; $;^{19}$ d. Druskieniki, near Hrodna 1847) who wrote a number of philomath poems in Byelorussian as well as twenty-nine imitation folk songs.

Vincent Dunin-Marcinkievič (b. Paniuškievičy, near Babrujsk 1807; d. Lucynka, near Minsk 1884), who in addition to his own name also used the pseudonym Naum Pryhavorka, is one of the most important writers of the century. Like Barščeŭski, Rypinski and Cačot, he came from the minor gentry, and was, in fact, a nephew of the well-known Metropolitan of Mahiloŭ, Bohuš Siestrencevič (b. 1731; d. 1826). After school in Babrujsk he entered Vilna university, but left in 1827, his medical training uncompleted. For the next twelve years he occupied government posts in various parts of Byelorussia, but in 1839 bought and retired to Lucynka where the remainder of his days were spent. Both in the volume of work that he actually published and in his progressive attitude towards the language (in particular the vocabulary), Dunin-Marcinkievič established Byelorussian literature on a firm foundation and considerably expanded (notably in his translation of Pan Tadeusz) ${ }^{20}$ the expressive resources of the language as a literary medium.

Other writers of the middle of the century who shared DuninMarcinkievič's social background and were, indeed, friendly with him include Adam Płuh and Arciom Viaryha-Dareŭski: Płuh (the literary pseudonym of Anton Pietkievič: b. Zamoście, near Minsk 1823; d. Jakutsk 1903) is important as the author of the first Byelorussian short story; on the other hand, almost all the works of ViaryhaDareŭski (b. Kubličy, Lepiel region 1816; d. Irkutsk 1884) have been lost; he is chiefly remembered for his album which contains a number of original Byelorussian poems (as well as a good deal of Polish material) written between 1858 and 1863. Finally, Krótkie zebranie nauki chrześcianskiey (1835) deserves attention, being the first printed book in the modern Byelorussian language. Although it is linguistically characteristic of north-east Byelorussia, Karski ${ }^{21}$ attributes the book to M. K. Babroŭski (b. Hrodna region 1784) the discoverer of the Codex Suprastiensis and Professor of Philosophy and Theology at Vilna university where he was also the leader of a Byelorussian circle, a circumstance which in 1824 led to his dismissal. Elementarz dla dobrych dzietok katolikou (1862), the other important religious text of the nineteenth century, is also linguistically characteristic of north-east Byelcrussia, but it is less consistent than

19. Until recently there has been some doublt about both the date and the place of Cačot's birth. On this point and for an outline of his life and work sec the present author's 'Jan Cačot in Byclorussian and Polish Literature', T'he Journal of Byelorissian Studies, II, 1, London, 1969, pp. 57-68.

20. Only the first two chapters have survived.

21. Bel, III, 3, p. 78; Bel, III, 2, p. 150. Kramko considers on linguistic grounds that he was probably only one of several compilers (HBLM, II, pp. 27-8). 
Krótkie zebranie and contains a number of Russicisms and Polonisms. Its publication was organised by A. I. Askierka (b. Rudakova, Rečyca region 1830; d. Vidzy, Brasłaŭ region 1911), a liberal who after exile to Siberia for his part in the 1863 uprising, in 1875 moved to Warsaw where he spent almost all the remainder of his life.

Publicist works, although of a very different kind from Krótkie zebranie and Elementarz, were to dominate the 1860s. The majority of writers in the first half of the century had been clearly orientated towards Polish culture, being members of the šlachta whose position had at first changed little when, with the partitions of Poland, Byelorussia became part of the Russian empire. Polish cultural influence, however, suffered a severe set-back when Vilna university which had flourished from the beginning of the century was closed by the authorities after the 1831 uprising. Even more damaging to the development of Byelorussian literature was a government circular in 1859 banning the use of the Latin alphabet.2. Other repressive measures followed, and with the uprising of 1863 a total ban was placed on the Byelorussian language that was not lifted until 1889. Earlier Byelorussian literature, like Polish regional literature, had employed mainly verse forms, both to facilitate memorising and distribution in the face of censorial oppression, and for greater closeness to the folk models on which much of it was based. The publicist literature of the $1860 \mathrm{~s}$, however, both legal and illegal, used prose as well as verse for the various tracts that were disseminated and circulated at the time of Emancipation and the 1863 nationalist uprising.

The most important of the nationalists was Kastuś Kalinoŭski (b. Mastaŭlany, Vaŭkavysk region 1838; d. Vilna 1864) who under the name of Jaśka haspadar z pad Vilni published seven issues of $M u z ̌ y c-$ kaja praŭda, a revolutionary news-sheet, as well as a letter 'from under the gallows' exhorting his countrymen to resist their Russian oppressors. Pismo ad Jaśka haspadara (1864) although formerly also attributed to Kalinoŭski ${ }^{23}$ is now thought to be by members of Agaton Giller's nationalist circle. ${ }^{24}$ Other writers with the same anti-Russian outlook, although not always sharing Kalinoŭski's democratic views, were Vinceś Karatynski (b. Siališča, Navahrudak region 1831; d. War’saw 1391), Vładysłaŭ Syrakomla (the literary pseudonym of Ludvik Kandratovič: b. Smolkava, Babrujsk region 1823; d. Vilna 1862), and F. Pčycki, the author of Kryŭda $i$ praŭda about whom little else is known. Their works are paralleled by various anonymous tracts such as the Predśmiertny rozhowor Pustelnika Pietra, Rqd

22. Amongst the first casualtics was Dunin-Marcinkievič's translation of Pan Tadeusz, seized and burned by the authcrities as soon as it appearcd. Earlier, the first performance of Sielanka on 9 February 1852 had coincided with a decree forbidding stage performances 'in the language of the common people'. This and other similar measures ensured that the majority of writers were not familiar with each other's wo:l and, thus, delayed the development and normalisation of the literary language.

23. Bel, III, 3, p. 86.

24. HBLM, II, p. 62; H. Kisialoŭ, Siejbity viečnaha, Minsk, 1963, p. 16. 
narodowyi polskoj, Hutorka dwóch susiedou, and Hutorka staroho dzieda. The latter, although bearing 'Poznań' on the title-page, was, in fact, printed at Schwarze's printing press in Białystok. ${ }^{25}$ It is now widely attributed to Karatynski. ${ }^{2}$ A rather feeble counter to these anti-Russian brochures was made in the officially inspired but crudey written Rasskazy na belorusskcm narečii (Vilna, 1863).

Parallel to the essentially nationalist tracts of the 1860 s were several anonymous works which emphasised the oppressed condition of the peasantry, without necessarily blaming the Russian tsar for their ills. Schod was recorded in 1863 by a certain Miss Jarmolinska who gave it to the ethnographer Šejn in the 1880s; it remained, however, in the unpublished part of his collection, along with several other versions of it from various regions of Byelorussia. Razhovor Danity i Ściepana (pro volu) and its 'pendant' Razmova pana $z$ chtopam were clearly written on the eve of Emancipation; in 1900 the former was inscribed by Ja. A. Vasilleŭ of Minsk in the album of the poet Albert Paŭłovič as a work of Dunin-Marcinkievič, but as this bitter lament is quite out of lieeping with the latter's manner and style, there seems even less justification for such an attribution than in the case of Bachrym.

Despite its repressive policy towards the Byelorussian language, the Russian government did not hesitate to use it for its own ends, and there appeared in Mahiloŭ two lengthy publications aimed at answering the dissidents' criticism. The first, Biasieda staraho volnika (1861), is sometimes attributed to Apanas Kisiel, Gevernor of Mahiloŭ province, who was reputed to be able to write in all the dialects of the region. ${ }^{27}$ The work (written in prose) is lexically rather russianized, although the spelling, generally of a very low standard, shows some Ukrainian influence. The two verse tracts of Franc Fieliks Błus published in the same year are no less banal, and even more russified than the Biasiedr. The author (of whom nothing is known to this day) attempts in some 1500 lines of doggerel verse to rationalise the peasants' continuing lack of freedom despite the much-publicised Emancipation.

If the writings of the early ethnographers had aroused foreign academic interest in the Byelorussian language and culture, so the various revolts, particularly that of 1863 , drew the attention of the Russian public at large to the very existence of Byelorussia. Both Katkov's Moskovskije vedomosti and Aksakov's Den' paid tribute to the 'blood brothers whom they had overlooked'.28 Ironically, it was

25. PXIX, p. 65. The practice of supplying false information on the title-pange was common in the second half and at the turn of the century as a means of deceiving the censor. Janka Łučyna's Viazanka, for example, bore the words 'in the Bulgarian language'.

25. Bel, III, 3, p. $72 ; H H$, p. 140; H. Kisialoŭ, 'V. Dunin-Marcinkievič i paŭstańnie 1863 hoda', Polymia, 5, Minsk, 1961, pp. 119-38.

27. NHBL, p. $92 ;$ PXIX, p. 8. Other authorities believe that the work may have simply been published on his instructions. See Bel, III, 3, pp. 72 and 91 ; $H H$, p. $137 ; H B L M$, II, p. 61.

28. N. P. Vakar, Belorussia. The Making of a Nation, Cambridge, Mass., 1956, p. 73 . 
at this time that the Imperial authorities imposed complete silence on the Byelorussians: the ban on printing was not lifted until 1889, and no periodical publication in the vernacular was allowed before 1906. As in the preceding period, however, a number of anonymous socialist publications appeared clandestinely, many of them printed abroad.

Pro bahactvo da b'ednosć (1881) was a translation of a tract by Drahomanov who, like the supposed translator Serhij Podolins'kyj (b. Jaroslavka, Cerkessk region 1850; d. 1891) ${ }^{29}$ worked in Geneva on the staff of the emigré Russian newspaper Vol'noje slovo. Although the spelling reflects Ukrainian influence, the vocabulary is relatively free of Ukrainianisms.

The history of Dziadzkka Anton is complex. In 1874 the Bessarabian revolutionary V. Je. Varzar (b. 1851; d. 1940) published in Moscow a pamphlet entitled Chitraja mechanika ili pravdivyj rasskaz o tom, $k u d a$ den'gi idut. Four years later there appeared in Polish Opowiadanie starego gospodarza (s. 1.), Szymon Dickstein's reworking of a Ukrainian version of Chitraja mechanika made by N. P. ZubkuKodreanu (Nicolaie Zubcu-Codreanu: b. 1850; d. 1878), a Bessarabian socialist of Ukrainian origin. ${ }^{30}$ Unfortunately, this Ukrainian version appears to have been lost. In 1882 Dickstein (using the pseudonym Tomek Kujawczyk) republished Opowiadanie in Warsaw, this time under the title of Ojciec Szymon, and in this form it went through five further editions: Geneva 1883, Warsaw 1895, ${ }^{31}$ London 1896 and 1902, and Cracow 1910. Dziadźka Anton, which Karski incorrectly attributes to Hurynovič ${ }^{32}$ is, in fact, a direct translation of Ojciec Szymon ${ }^{33}$ by the polyglot Polish revolutionary Marjan Abramowicz (b. 1871 ; d. 1925). ${ }^{34}$ The brochure's title-page gives the place of publication as Vilna, but, like so much of Byelorussian propagandist literature in the nineteenth century, it was actually published abroad — in Tilsit, 1892.

Another anonymous work which seems on internal evidence to have been written in the mid-1880s is Hutarka $\breve{u}$ karčmie, recorded by Kandraś z-pad Dokšyc in Ludvinaŭ, 1891. Bende considers that the author may have been Bahuševič, as the latter (probably) taught in Dokšycy at one time. ${ }^{35}$ Francišak Bahuševič (b. Kušlany, Ašmiany

29. Bel, III, 3, p. 154 .

30. S. Aleksandrovič ('Historyja z Dziadźka Anton', Litaratura i mastactva, 61, Minsk, 1961) incorrectly supposes that Zubku-Kodreanu was a pseudonym of Varzar. For more information about him see Nikolaj Petrovič ZubkuKodreanu (Biografičeskij očerk), s. n., Geneva, 1879.

31. Ż. Korman (Materjały do bibliografii druków socjalistycznych na ziemiach polskich $w$ latach 1866-1918, Warsaw, 1935, p. 159) incorrectly dates this edition 1891.

32. Bel, III, 3, p. 77.

33. In 1903 another Byelorussian version of Ojciec Szymon, Hutorka ob tym, kudy mužyckije hrošy iduć, was published anonymously in London by J. Kaniowski of Leytonstone, on behalf of the Polish Socialist Party in Lithuania.

34. Abramowicz was born in 'Tver' and studied at Moscow university.

35. L. Bende, 'Hutarka ŭ karčmie', Potymia, 2, Minsk, 1956, pp. 140-53. 
region 1840; d. Svirany, Ašmiany region 1900) whose main literary pseudonyms were Maciej Buračok and Symon Reŭka, was important as one of the most prolific and gifted of Byelorussian poets, and as the chief propagandist of the national revival at the end of the century. Widely travelled, he lived much of his life in the Ukraine, as well as in Russia, Poland, Vilna and various parts of Byelorussia. The language of his poetry is sometimes criticised for the number of foreign elements it contains, but they are not particularly numerous in relation to the overall length of his work; he is, however, very inconsistent both orthographically and lexically.

Amongst Bahuševič's younger contemporaries were Janka Łučyna (the literary pseudonym of Ivan Niesłuchoŭski: b. Minsk 1851; d. Minsk 1897) who on account of the purity of his language exercised some influence on the following generation of poets (including Kupała and Kołas), Fieliks Tapčeŭski (b. Lepiel region) whose principal pseudonym was Chvelka z Rukšenic, and Adam Hurynovič (b. Kavali, Vilejka region 1869; d. Kavali 1894) who combined the roles of ethnographer, ${ }^{36}$ poet, revolutionary and member of the editorial committee of Homan. ${ }^{37}$ Eučyna and Hurynovič both made translations from other Slavonic languages (notably Polish and Russian), and in doing so they were following a well-established tradition of Vilna (an outstanding example being Dunin-Marcinkievič's Pan Tadeuš) that looked back to such works of the mediaeval period as The Romance of Alexander and The Tale of Attila. Another important translation was of V. Garšin's short story Signal published in Moscow in 1891. Although anonymous, it is attributed with some certainty to Jadvihin $\mathrm{S}$. (the literary pseudonym of Anton Lavicki: b. Dobaśnia, Rahačoŭ region 1868; d. 1922) who is thought to have made the translation whilst in prison. Its language is remakably pure Byelorussian, particularly by comparison with that of Hurynovič.

At about this time A. O. Sunkievič (the literary pseudonym of Mikałaj Marozik: b. Łaŭryšava, Navahrudak region) published a short verse, and A. Pščołka (b. Viciebsk region c. 1870) a series of macaronic prose sketches depicting humorous scenes from peasant life, of which only $U$ tijatri seems to be entirely in Byelorussian. One of the most important writers of this period is Alaksandr Jelski (b. Zamoście, near Minsk 1834; d. Zamoście 1916), a wealthy philanthropist, historian, ethnographer and versifier who, in addition to a considerable body of historical and ethnographical work in Polish, published a Byelorussian translation of the first chapter of Pan Tadeusz and a number of didactic brochures (in both prose and verse) which were directed towards the moral improvement of the peasants. His language is heavily polonised, particularly in the

36. See A. Hurynowicz, 'Zbiór rzeczy białoruskich (7. gminy Wiszniewskiej, parafii Żodziskiej, pow. Swięciańskiego, gubernii Wileńskiej)', Krakowskie Towarzystwo Naukowe. Zbiór wiadomości do antropologii krajowej, XVII, Cracow, 1893, pp. 136-200.

37. An obscure underground publication of which only the title was in Byelorussian, the remainder being in Russian. 
translation, but it also shows a number of Russicisms and invented forms, as well as various orthographic and phonetic inconsistencies.

The last important writer of the nineteenth century was Alhierd Abuchovič (b. Słuck region 1840; d. Słuck region 1898) ${ }^{38}$ who, under the pseudonym of Count Bandinelli, wrote some extremely interesting memoirs, two satirical fables, and numerous translations from English, French, German, Italian, Polish and Russian. During his lifetime both the original works and the translations were circulated in manuscript, but almost all the translations have now been lost. In style and manner Abuchovič looks forward to the twentieth century, but his language contains a high proportion of Polonisms and invented forms. Criticised by Bahuševič on linguistic grounds he replied:

$$
\begin{aligned}
& \text { 'U havorcy jość ružnica } \\
& \text { Miž majeju i Tvajej: } \\
& \text { Majej - puščy, Ptyč hranica, } \\
& \text { Ty - Panarski sałaviej . . '39' }
\end{aligned}
$$

Thus, by the end of the century, although no firm orthographical or lexical norms had been established, and although no literary or other periodical publication existed through which such norms might be worked out, the ground was prepared, as it were, for the next great epoch in the development of the Byelorussian language and literature, the period of Naša niva.

\section{BIBLIOGRAPHY}

Alhierd Abuchovič, Papiery, c. 1895, (excerpts) in Homan, 33-40, 49, Vilna, 1916.

Staršyna, s. a., in $H C h$, p. $216 .{ }^{40}$

Waŭlcałak, s. a., in $H C h$, p. $215 .{ }^{41}$

Sud, s. a., in W. Eastoŭski (ed.), Rodnyje zierniaty. Knižyca dla školnaho čytańnia, Vilna, 1916, p. 125.

38. Bel, III, 3, p. 76; Biełaruskaja savieckaja encykłapiedyja, I, p. 44. Other sources give the date of Abuchovič's death as 1905: S. Majchrovič, Narysy biełaruskaj litaratury XIX stahodździa, Minsk, 1959, p. 287; V. V. Barysienka (ed.), Biełaruskija piśmieńniki druhoj pałovy XIX sıahodździa, Minsk, 1956 (subsequently referred to as $B P D P$ ), p. 344.

39. For further details of Abuchovič's attitude to the literary language see 'Litaraturnaje apraŭdańnie', section 10 of his Papiery.

40. This was not the first printed edition, for Harecli states that his source was 'a calendar' (p. 264). The latter was not, however, the Bietaruski kalendar na 1915 (Vilna, 1914) as is suggested in BPDP, p. 344.

41. See note 40. 
Woŭk i lisica, s. a., in W. Eastoŭski (ed.), Rodnyje zierniaty. Knižyca dla školnaho čytańnia, Vilna, 1916, p. 123.

Ab żỳci i śmierci pjànicy, in M. Federowski, Lud białoruski na Rusi Litewskiej, III, 2, Cracow, 1903, pp. 32-3.

H. Arcimoŭski, Pani Tvardoŭskaja, c. 1840, recorded by V(acłaŭ) モ(astoŭski) in Naša niva, 19-20, Vilna, 1915.

Paŭluk Bachrym, Zahraj, zahraj, chłopcze mały, c. 1828, in Powieść $z$ czasu mojego, czyli przygody litewslie, s. n., London, 1854, pp. $263-4 .^{42}$

Francišak Bahuševič, Dudka bietoruskaja Macieja Buraczka, Cracow, 1891.

Jaśnie Vialmožnaj Pani Areščyce, 1891, in Varta, 1, Minsk, 1918 , pp. $15-16$.

Tralalonaczka, Cracow, 1892. 1894.

Smyk białoruski Szymona Rewki z pad Barysawa, Poznań,

Maryja Pia nad zalaznaj strunoj zapanuje, 1897, in the album of Żćcioja Platrovič(anka), first published by Anton Euckievič́ni kaŭ', Zapisy Biełaruskaha navukovaha tavarystva, 1, Vilna, 1938 (subsequently referred to as $\check{Z} T F B$ ), p. 23.

Kab ja moh napisać toje, što u dumcy, 1897, in the album of Stanisłava Piatrovič(anka), first published by K. Duž-Dušeŭski in 'Aŭtohraf Franciška Bahuševiča', Kryvič, 5, Kaunas, 1923, p. 51. Kamu dudka pastuszna, 1897, in the album of Maryja Piatrovič(anka), first published in ŽTFB, pp. 22-3.

Sabraŭszysia na try czoŭna, 1897, in the album of Alona Piatrovič(anka), first published in $\check{Z} T F B$, pp. 22-3.

- Viecier dźmie $i$ vyje, c. 1897, first published by Anton Łuckievič in $\check{Z} T F B$, p. 27.

Dziadzina in Naša niva, 25, Vilna, 1907.

Palasoǔščyk in Naša niva, 10, Vilna, 1907.

Sviedka in Naša niva, 9, Vilna, 1907.

Svinni $i$ barany (a translation from the Polish of Bartels), s. a., in Homan, 54, Vilna, 1916.

Jan Barščeŭski, Ach czymże twaja, dzieweńka hałouka zaniata?, 1809 , in A. Abramowicz, 'Kilka melodyj ludu białoruskiego', Rocznik literacki, StP, 1843, pp. 203-4.

Rabunki mużykou, c. 1812, (excerpts) recorded by Romuald Podbereski in 'Białoruś i Jan Barszczewski', his introduction to Jan Barszczewski, Szlachcic Zawalnia czyli Białoruś w fantastycznych opowiadaniach, StP, 1844, pp. xxvii-xxxii.

Harelica, c. 1843?, in A. Abramowicz, 'Kilka melodyj ludu białoruskiego', Rocznik literacki, StP, 1843, p. 204.

Biasieda staraho volnika $z$ novymi pra ichnaje dzieło, s. n., Mahiloŭ, 1861.

42. Authorship of this book, long uncertain, is now attributed to the Navahrudak lawyer Ignacy Jackowski. See Polski słownik biograficzny, X. WrocławWarsaw-Cracow, 1962-4, p. 276. 
Franc Fieliks Eìus, Reč́ starovojta krest'janam o svobode (dlja narodnogo čtenija) in Mogilevskije gubernskije vedomosti, 51, 60, Mahiloŭ, 1862 .

Reč́ starovojta (dlja čtenija moim zemljakam) in Mogilevskije gubernskije vedomosti, 61, Mahiloŭ, 1862.

Chimka z Hankoju, dźvie mołodzicy recorded by I. I. Nosovič in Zapiski Imperatorskogo russkogo geografičeskogo obščestva po otdeleniju etnografii, V, StP, 1873 (subsequently referred to as ZIRGO, V), pp. 70-1.

Ci dobre my zrobili pokinuvši uniju?, s. n., in Rasskazy na belorusskom narečii, Vilna, 1863, pp. 13-18.

Jan Čačot, Jeżowe, Jaroszowe and Adamowe i Tomaszowe, 1819, in Archiwum filomatów, III. Jan Czubek (ed.), Poezja filomatów, Cracow, 1922, pp. 76-84, 187, 201-3.

Własne piosnki wieśniacze in Piosnki wieśniacze $z$ nad Niemna i Dźwiny, $z$ dołaczeniem pierwotwornych $w$ mowie sławiano-krewickiéj, Vilna, 1844, pp. 74-128.

Da mitych mużyczkōú in Piosnki wieśniacze z nad Niemna $i$ Dźwiny, niektóre przystowia $i$ idiotyzmy, $w$ mowie stawianokrewickiej, s postrzeżeniami nad nia uczynionemi, Vilna, 1846, pp. $62-3$.

Dudar, s. a., in I. Sałamievič, 'Vierš paŭstanca 1863 hoda', Litaratura i mastactva, 95, Minsk, 1967.

V. I. Dunin-Marcinkievič, Sielanka, Vilna, 1846.

Powinszowanie Wojta Nauma, 1854, in Hapon, Minsk, 1855, pp. 73-6.

Hapon, 1855, in Hapon, Minsk, 1855, pp. 11-71.

Wieczernice i obłakany, Minsk, 1855.

Kupałła in Ciekawyś? Przeczytaj!, Minsk, 1856, pp. 13-35.

Wiersz Nauma Pryhoworki, 1856, in Dudarz białoruski, czyli wszystkiego potrosze, Minsk, 1857, pp. 115-7.

pp. 94-108.

Bylicy, raskazy Nauma, 1857, in Połymia, 8-9, Minsk, 1946,

Chalimon na karanacyi, 1857, (abbreviated version) in Potymia, 8-9, Minsk, 1946, pp. 108-27.

Szczerouskije dażynki in Dudarz białoruski, czyli wszystkiego potrosze, Minsk, 1857, pp. 77-114.

Trawica - brat-siestryca, 1857, in Biełaruś, 11-12, Minsk, 1945 , pp. $20-13$.

Pan Tadeusz, pa polsku napisau Adam Mickiewicz. Na biełaruskuju hutarku pieraviarnuu Wincuk Marcinkiewicz, Vilna, 1859. 1918.

Pinskaja szlachta, 1866, in Volnaja Biełaruś, 30-1, Minsk,

Zaŭtra spasa, każuć ludzie, 1868, in Zachodniaja Biełaruś, Vilna, 1923, p. 121. 
Zaloty, 1870, in Sceničnyja tvory, Minsk, 1918, pp. 77-113. Dziadźka Anton abo hutarka ab usim czysta szto balić, a czamu balić - nie wiedaim, s. n., Vilna (Tilsit), 1892.

Elementarz dla dobrych dzietok katolikou, s. n., Warsaw, 1862.

Enieida navyvarat, c. 1820?, in Majak, XXIII, Smes', StP, 1845, pp. 33-9.

Enieida navyvarat, c. 1820?, in Smolenskij vestnik, 10-11, Smolensk, 1890.

N. F., Nočču ü siale, s. a., in Kalendar' Severo-Zapadnogo Kraja na 1889 god, Moscow, 1889, p. 135.

Hej, kab nam być viesielej recorded by I. I. Nosovič in ZIRGO, V, pp. 106-7.

Horevid, Ja kliču vas . . . c. 1890, in Kryvič, 12, Kaunas, 1926-7, p. 5. Palakom u dzień 3-ha Maja, 1891, in Ruń, 1, Minsk, 1920, p. 8.

Adam Hurynovič, Bor, s. a., in Kałośsie, 1, Vilna, 1935, p. 30.

— Da Macieja Buračlka, s. a., in Biełaruski zvon, 6, Vilna, 1921.

- Da žniva, s. a., in Kalośsie, 1, Vilna, 1935, p. 32.

$B P D P$, p. 238.

Hibnuć zarańnia stolki ćviatkoŭ (from the Polish of Kasprowicz), s. a., in BPDP, p. 246.

Kali-ž u nas tak było, s. a., in BPDP, p. 223.

Katok, s. a., in Kałośsie, 1, Vilna, 1935, p. 33.

239.

Kazielčyk (from the Russian of Krylov), s. a., in BPDP, p.

Maroz (from the Russian of Nekrasov), s. a., in BPDP, p.

241.

Miejsca niačystaje, s. a., in BPDP, p. 241.

Pa žnivie, s. a., in BPDP, p. 233.

- Pierš dušyli pany, s. a., in Kałośsie, 1, Vilna, 1935, p. 32.

Raz u Zolkach, u dziareŭni, s. a., in BPDP, pp. 221-2.

- Rybak, s. a., in Katośsie, 1, Vilna, 1935, p. 33.

- Sto ty śpiš, mužyčok, s. a., in BPDP, pp. 217-8. ${ }^{\star 3}$

$216 .^{44}$ Sto $z a$ zvuk dy tak hromka razdaŭsia, s. a., in BPDP, p.

Vialla (a translation from the Polish of Mickiewicz), s. a., in $B P D P$, p. $243 .{ }^{45}$

Viasna ('Ty uznoŭ da nas viarnułaś...'), s. a., in Kałośsie, 1, Vilna, 1935, p. 31.

- Viasna ('Zdrastvuj, krasnaja viasna...' - a translation from the Polish of Kasprowicz), s. a., in BPDP, pp. 244-5.

Viečny revolucyjanier (a translation from the Ukrainian of Franko), s. a., in BPDP, pp. 247-8.

43. Although this poem appeared in at least one pre-war edition, the present compiler has been unable to locate it.

44. See note $\mathbf{4 3}$.

45. See note 43. 
Viesialčak (a translation from an unknown poet), s. a., in $B P D P$, pp. 249-50.

Vosien (a translation from the Russian of A. K. Tolstoj), s. a., in $B P D P$, p. 242.

Źciamnieła na dwory i cicha kruhom, s. a., in Kałośsie, 1, Vilna, 1935, p. 30.

Zviaryniec, s. a., in BPDP, pp. 234-5.

Hutarka Kuźmy s Apanasam recorded by I. I. Nosovič in ZIRGO, V, pp. 123-5.

Hutarka Paŭluka, s. n., in Vilenskij vestnik, 173, Vilna, 1898.

Hutarka $\breve{u}$ karčmie, c. 1885?, recorded in ms by Kandraś z-pad Dokšyc, Ludvinaŭ, 1891, and first printed in Połymia, 2, Minsk, 1956, pp. 144-52.

Hutorka dwóch susiedou, ms, s. n., 1862, in the Moscow State Historical Archive.

Hutorka staroho dzieda, s. n., Poznań, 1861.

Alaksandr Jelski, Vincułu Dunin-Marcinkieviču, biełaruskamu poetu, 1872, in Ju. Alelkavič, 'Stary Miensk u biełaruskich uspaminach', Biełaruś, 2, Minsk, 1920.

Pan Tadeusz. Paemàt Adama Mickiewicza piarałaży̆ù $z$ polskaho na biełaruski jazýk A. J., L'vov, 1892.

Synok, StP, 1895.

'Vybirajmasia u pročki!' Skarej u Tomsk!!, StP, 1896.

1900.

Kastuś Kalinoŭski, Do Ludu Białoruskiego. Pismo $z$ pod szubienicy Konstantego Kalinowskiego, 1861, in Agaton Giller, Historyja powstania narodu polskiego w 1861-4, I, Paris, 1867, pp. 327-35. Mužyckaja praŭda, Vilna, 1862 (Nos 1-6) - 1863 (No 7).

Mikołaj Karatkievič, Białoruski dudaru, 1858, in the album of A. Viaryha-Dareŭski, first printed in HCh, pp. 173-4.

Bruna Karatynski, Chto našaj mužyckaj movaj, s. a., in S. Ch. Aleksandrovič, A. A. Łojka, V. P. Rahojša, Biełaruskaja litaratura XIX stahodździa, Minsk, 1971 (subsequently referred to as BLXIX), p. 121.

Vinceś Karatynski, Daliboh-to, Arcim..., 1858, in the album of A. Viaryha-Dareŭski, first printed in BLXIX, pp. 107-8.

Ustavajma, braccy, Vilna, 1858.

1912.

Tuha na čužoj staranie, 1864, in Naša niva, 49-50, Vilna,

Kinuŭ-rynuŭ paŭstańnie, s. a., (excerpts) in BLXIX, pp. 339-41.

D. K-ko, Muohitki, s. a., in Kalendar' Severo-Zapadnogo Kraja na 1899 god, Moscow, 1899, p. 135.

Krótkie zebranie nauki chrześciańskiey dla wieśniaków mówiących jezzykiem polsko-ruskim wyznania Rzymsko-Katolickiego, s. n., Vilna, 1835. 
Ihnaci Lehatovič, Skaży wielmożny panie in Bojan, 1, Vilna, 1838, p. 224.

Janka Łučyna, Busiet (a translation from the Polish of Kondratowicz) in Severo-zapadnyj kalendar' na 1893 g., Minsk, 1892, pp. 21-2.

Dabradzieju artystu Mańko, s. a., in BPDP, pp. 126-7.

Horść pšanicy (a free translation from the Polish of Kondratowicz) in Severo-zapadnyj kalendar' na $1892 \mathrm{~g}$., Minsk, 1891, pp. $37-40$.

Jamščyk (a translation from the Polish of Syrakomla) in Severo-zapadnyj kalendar' na 1893 g., Minsk, 1892, pp. 33-5.

- Karšsun, s. a., in Viazanka, StP, 1903, pp. 8-9.

- Nadto sałodkija dumki (a translation from the Polish of Kondratowicz) in Severo-zapadnyj ka?endar' na 1893 g., Minsk, 1892, pp. 31-2.

p. 3 .

Nie ja piaju - narod Božy, s. a., in Viazanka, StP, 1903,

- Pahudka, s. a., in Viazanka, StP, 1903, p. 4.

Pakul hod novy nastanie na śviecie in Severo-zapadnyj kalendar' na 1892 g., Al'manach, Minsk, 1891, pp. 1-2.

Rodnoj staroncy in Severo-zapadnyj kalendar' na $1892 \mathrm{~g}$., Minsk, 1891, pp. 23-4.

Sivier, s. a., in Viazanka, StP, 1903, p. 10.

Staraść nie radaść, s. a., in BPDP, pp. 129-31.

- Stary laśnik in Severo-zapadnyj kalendar' na $1893 \mathrm{~g}$., Minsk, 1892, pp. 12-14.

Sto dumaje Janka, viezučy drovy $\breve{u}$ horad, s. a., in Viazanka, StP, 1903, pp. 10-11.

- Sto ptuški kazali, s. a., in Viazanka, StP, 1903, pp. 4-5.

Vsej truppe g-na Starickogo Belorusskoje slovo, s. a., in $B P D P$, p. 125.

- Viasna in Minskij listok, 28, Minsk, 1891.

- Viasnovoj poroj in Minskij listok, 20, Minsk, 1889.

Zahodzić sonce za hory (an excerpt from a longer poem, Hanusia) in Minskij listok, 70, Minsk, 1889.

Maładzikòwa Hùtarka in M. Federowski, Lud białoruski na Rusi Litewskiej, III, 2, Cracow, 1903, pp. 73-4.

Ihnat Mihanovič, Imianinnaje vinšavańnie Ihnata Śliŭki, (excerpt) in BLXIX, pp. 256-7.

Edward N., Nu bratoczku, 1858, in the album of A. Viaryha-Dareŭski, first printed in BLXIX, p. 109.

Novejšije stichi (Sirotinka; Gorkij p'janica; 'A što ŭ miri javlajetca usio biespotešno ...'; P'janica; 'Sto ja komu vinovat...'; Lavrija; 'U chram idi, stromko stoj...'; 'Približajetca koniec vieku...'; 'Niema ciapiericia vo usiom śvieci pravdy...'; 'Ach ty śmierc', moja śmierc'! . .'; 'Prošli mnohija lety ...'; Pravda; 'Niema ciapier pravdy vo ŭsiom śvieci ...'; Bohač) in Je. R. Romanov, Belorusskij sbornik, I, 5, Viciebsk, 1891, pp. 431-7. 
Oj, viaśnica, viasna in P. V. Sejn, Materialy dlja izučenija byta $i$ jazyka russkogo naselenija severozapadnogo kraja, I, 1, StP, pp. 127-8.

Panskaja łaska in P. F. Al'chimovič, Sbornik belorusskich narodnych legend, bylin i pesen', s opisanijem nekotorych obrjadov, obyčajev, prazdnikov i igrišč krest'jan Sebežskogo ujezda Vitebskoj gubernii, $\mathrm{ms}, 1882-90$, pp. $39 \mathrm{~b}-45 \mathrm{~b}$, in the Scientific Archive of the Geographical Society, Leningrad.

F. Pčycki, Kryŭda $i$ praŭda. Hutarka biłaruskaja, 1863, a hectographed brochure preserved in the Academy of Sciences of the USSR (Leningrad branch).

Pieśni nabożnyja, Warsaw, 1861.

Pieśń na božy čas, c. 1863, in H. Kisialoŭ, 'Stary sšytak', Litaratura $i$ mastactva, 18, Minsk, 1963.

Pismo ad Jaśka Haspadara $z$ pad Wilni da mużykou ziemli polskoj, c. 1864, in Agaton Giller, Historyja powstania narodu polskiego $w$ 1861-4, I, Paris, 1867, pp. 326-7.

Adam Płuh, Kručanaja baba, Snoŭ, 1849.

Pod dudu, s. a., in I. Karabicz, 'Słowo o pieśni', Nowiny, 287, Warsaw, 1882.

Pozdravitel'noje stichotvorenije so dnjom angela, c. 1830, s. n., in Cytovič, 'Slova dva o jazyke i gramotnosti Beloj-Rusi', Majak, IX, 17, Smes', StP, 1843, pp. 33-8.

Prečistaja siered noči recorded by I. I. Nosovič in ZIRGO, V, pp. 86-9.

Predśmiertny rozhowor Pustelnika Pietra, s. n., Kiev, s. a.

Pro bahactvo da b'ednosć. P'eraklad s ukrajinskaho, s. n., Geneva, 1881.

Vilhielm Pratasievič, Susiedčyk Haviecki, s. a., in Ja. Sałamievič, 'Paet-sielanin Vilhielm Pratasievič', Litaratura $i$ mastactva, 85, Minsk, 1969.

A. Pščołka, U tijatri in Očerki iz žizni belorusskoj derevni, Viciebsk, 1899 , pp. $104-7$.

Rad narodowyi polskoj, s. n., s. 1., 1863.

Razhovor Danity i Sciepana (pro volu) in P. V. Sejn, 'Krepostnoje pravo $\mathrm{v}$ narodnych pesnjach', Russkaja starina, XLIX, StP, 1886, pp. 674-8.

Rozmowa pana $z$ chtopem po uwtaszczeniu, s. a., in M. Federowski, Lud białoruski na Rusi Litewskiej, III, 2, Cracow, 1903, p. 18.

Radvan Rypinski, Niaczyścik in Poezije, London, 1853, pp. 127-38.

Tyż sam, susiedźka, chacie ŭ.., 1860, in the album of $\mathrm{A}$. Viaryha-Dareŭski, first printed in $\mathrm{HCh}$, p. 102.

Francišak Savič, Tam blizko Pińska, s. a., in E. Pawłowicz, Wspomnienia $z$ nad Wilji i Niemna, L'vov, 1883, pp. 94-6.

Schod, c. 1862, in Biełaruś, 10, Minsk, 1945, pp. 18-19.

Sihnat (a translation from the Russian of Garšin), s. n., Moscow, 1891.

Skazka nie skazka, byl nie byl, ale tak byvaić, s. n., in Rasskazy na belorusskom narečii, Vilna, 1863, pp. 29-32.

Staryj Vosip borodatyj recorded in ZIRGO, V, p. 70. 
I. Staŭbun, Chto ja? in Kaladnaja pisanka na 1904 hod, StP, 1903.

Vajnisłaŭ Kanstancinavič Sulima-Savič-Zabłocki, Da pierapiołki, c. 1870?, in Biełaruś, 4, Minsk, 1946, p. 25.

U rodnaj ziamli, c. 1870?, in Biełaruś, 4, Minsk, 1946, p. 24.

$Z$ čužbiny, c. 1870?, in Biełaruś, 4, Minsk, 1946, p. 24.

V. Syrakomla, Dobryja vieści, 1848, in Hutorka staroho dzieda, s. n., 2nd edition, Paris, 1862.

Vilna, 1912.

A. O. Sunkievič, Sciapan i Taciana in Minskij listok, 18, Minsk, 1889.

Ijachim Tamaševič, Jezusu Ćviecinskamu skarha na Daŭmantaŭ, c. 1890 ?, in BLXIX, p. 258.

Fieliks Tapčeǔski, Hrošy i praca, 1890, in Połymia, 12, Minsk, 1954, pp. $140-1$.

- Jon i jana, s. a., in Połymia, 12, Minsk, 1954, pp. 142-3.

__ Panskaje ihryšča, s. a., in Vilenskij vestnik, 70, Vilna, 1889.

Saŭsim nie toje, što było, 1890, in Połymia, 12, Minsk, 1954,

pp. $137-40$.

Viečarynka, $188^{*}$, in BPDP, pp. 197-8.46

Taras. Belorusskaja poema in Minskij listok, 37, Minsk, 1889.

Taras na Parnase in Smolenskij vestnik, 37, Smolensk, 1890.

Taras na Parnase. Belorusskaja poema, Viciebsk, 1896.

Taras na Parnase. Sutočnyj rasskaz v stichach na belorusskom jazyke, Hrodna, 1896.

Taras na Parnasie in M. Dovnar-Zapol'skij, 'Dunin-Marcinkievič i jego poema Taras na Parnase. Očerk iz istorii belorusskoj etnografii, Vitebskije gubernskije vedomosti, 2-3, 6-7, 26-7, Viciebsk, 1896.

Taras polesovščik in Je. Radimič (Je. R. Romanov), Milostivyj Osip, ili milosti choču, a ne žertvy, Viciebsk, 1896, pp. 51-9.

Hienryk Tatur, Pradki (a translation from the Polish of Syrakomla), s. a., in Kryvič, 12, Kaunas, 1926-7, p. 6.

Teatr, s. a., in Volnaja Bietaruś, 25, Minsk, 1918.

Jakub T-ki, Stowna z neba Božy dar, 1858, in the album of A. Viaryha-Dareŭski, first printed in $\mathrm{HCh}$, p. 174.

Arciom Viaryha-Dareŭski, Adaśka, rodny Adaśka, s. a., (excerpt from a longer poem in honour of Kirkor) in R. Ziemkiewič, Adam Honory Kirkor, Vilna, 1911, pp. 7-8.

Grzech 4ry hnieu, s. a., (excerpt) in Ruch muzyczny, 49, Warsaw, 1859.

Litwinam zapisaŭszymsia u moj Albom na Pażegnańnia, ms, 1858, first printed (?) in BLXIX, pp. 114-7.47

46. This is certainly not the first published edition of the poem, but the information given in BPDP (p. 341) that it appeared in Bietaruski kalendar na 1915 hod (Vilna, 1914) is incorrect.

47. It may well be to this poem that Vacłaŭ Eastoŭski refers in Naša niva under the title of Bratom Litvinom. He states that the manuscript of the latter is to be found in the editorial office of Naša niva. Vłast, 'Pamažycia!', Naša niva, 37, Vilna, 1913. 
Viasna hoła pierapała in Vitebskije gubernskije vedomosti, 26, Viciebsk, 1896.

Vinšovanije Savxścieja, c. 1831, in Illustracija, VII, Smes', StP, 1848, pp. 190-1.

Lavon Vitan-Dubiejkaŭski, Bura, 1893, in A. Maldzis, 'Dźvie znachodki', Litaratura i mastactva, 74, Minsk, 1969.

Ciahnie voŭk - paciahnuć voŭka, 1892, in Volnaja Biełaruś, Minsk, 7 January 1918.

Vot ciepier jaki lud stav recorded by I. I. Nosovič in 1848, and first published by him in ZIRGO, V, pp. 126-33.

Vot vidicie vy, dzieci, jakije ciapier ludzi na śviecie in Je. Radimič, Milostivyj Osip, ili milosti choču a ne žertvy, Viciebsk, 1896, pp. 21-2.

J. P. Vul, $K$ dudaru Arciomu at naddwinskaha mużyka, 1859, in the album of A. Viaryha-Dareŭski, first printed in HCh, pp. 174-5.

Ziemielka moja, s. a., in I. Karabicz, 'Słowo o pieśni', Nowiny, 288, Warsaw, 1882.

\section{LIST OF ABBREVIATIONS}

Bel Je F. Karskij, Belorusy, I-III, Warsaw, Moscow, Petrograd, 1903-21.

BLXIX S. Ch. Aleksandrovič, A. A. Łojka, V. P. Rahojša, Biełaruskaja litaratura XIX stahodździa. Chrestamatyja, Minsk, 1971.

BPDP V. V. Barysienka (ed.), Biełaruskija piśmieńniki druhoj pałovy XIX stahodździa, Minsk, 1956.

HBLM, II I. I. Kramko, A. K. Jurevič, A. I. Janovič, Historyja biełaruskaj litaraturnaj movy, II, IMinsk, 1968.

HCh M. Harecki, Chrystamatyja biełaruskaje litaratury XI vek - 1905 hod, Vilna, 1922.

HH M. Harecki, Historyja biełaruskaje litaratury, 4th edition, Minsk, 1926.

NHBL V. V. Barysienka (ed.), Narysy pa historyi biełaruskaj litaratury, Minsk, 1956.

PXIX A. Maldzis, Padarožža ŭ XIX stahodździa, Minsk, 1969.

ZIRGO, V Zapiski Imperatorskogo russkogo geoǵrafičesicogo obščestva po otdeleniju etnografii, V, StP, 1873.

ŽTFB Anton Euckievič, 'Žyćcio i tvorčaść Fr. Bahuševiča ŭ uspaminach jahonych sučaśnikaŭ', Zapisy Biełaruskaha navukovaha tavarystva, 1, Vilna, 1938. 